\title{
Accounting Regulations, Enforcement, and Stock Price Crash Risk: Global Evidence in the Banking Industry
}

\author{
Pejman Abedifar \\ Centre for Responsible Banking \& Finance, School of Management, \\ University of St. Andrews, UK \\ Ming Li* \\ Wuhan Technology and Business University \\ and Hubei Business Service D\&R Center, China \\ Dean Johnson \\ Michigan Technological University, USA \\ Liang Song* \\ University of Massachusetts Dartmouth, USA \\ Saipeng Xing* \\ Zhongnan University of Economics and Law \\ and Wuhan Technology and Business University, China
}

*Corresponding author. E-mail addresses: xingsaipeng@163.com (Saipeng Xing) Zhongnan University of Economics and Law and Wuhan Technology and Business University, China; lsong@umassd.edu (Liang Song) University of Massachusetts Dartmouth, USA; 36010526@qq.com (Ming Li) Wuhan Technology and Business University and Hubei Business Service D\&R Center, China.

We thank Prof. Kose John, Prof. Iftekhar Hasan, and Prof. Sudipta Basu for their valuable comments. Part of this work was conducted when Liang Song was a visiting scholar at the European Central Bank and Central Bank of Finland. Part of this work also was conducted when Ming Li was a visiting professor at the EMLYON Business School, France. This research was supported by a Summer Research Fellowship Program grant from the Office of the Provost at the University of Massachusetts Dartmouth, United States. The authors are listed alphabetically. 


\title{
Accounting Regulations, Enforcement, and Stock Price Crash Risk: Global Evidence in the Banking Industry
}

\begin{abstract}
This study uses the banking industry as a unique testing setting to examine the impact of accounting and enforcement regulations on stock price crash risk. We find that stocks are less likely to crash in countries with stricter accounting regulations and enforcement standards. More importantly, we provide evidence that the impact of accounting regulations is more significant in countries with stricter enforcement standards, suggesting that enforcement mechanisms and accounting regulations are complementary. We find that the main channels for accounting regulations and enforcement standards to affect stock price crash risk are regulations that strengthen information disclosure and improve the effects of direct supervision and external auditors. Our findings are robust after we include more control variables, employ regional regulatory developments as instrumental variables, conduct change regressions, use alternative measures of enforcement, and estimate in various subsamples. Our study has policy implications for how to design accounting regulations and enforcement mechanisms in a more effective manner.
\end{abstract}

JEL Classification Numbers: M41; M48; G21

Keywords: accounting regulations; industry-specific enforcement standards; stock price crash risk; banking industry 


\section{Introduction}

The extant literature (e.g., Ball, 2009; Kothari et al., 2009) proposes that managers do not want to disclose unfavorable operating outcomes. When the cost caused by unfavorable firm-specific information is too high for managers, they could disclose all such negative information, and as a result stock prices will crash (Jin and Myers, 2006). ${ }^{1}$ To solve the problem of managers' not disclosing, regulatory agencies have developed accounting regulations to improve financial reporting quality and to reduce information risk for external investors (Bushman and Smith, 2001). Enforcement of accounting regulations also is important, as the transparency benefit gained by the adoption of high-quality accounting regulations depends on the effectiveness of enforcement (Committee of European Securities Regulators, 2003; Securities and Exchange Commission, 2000). There are variations in enforcement mechanisms across countries, however, and governments are regularly designing more enforcement regulations (e.g., Burgstahler et al., 2006; Daske et al., 2008; Landsman et al., 2012; Leuz et al., 2003; Li, 2010). How the benefits of accounting regulations are affected by the quality of enforcement mechanisms, however, remains an empirical question. LaPorta et al. (2006) show that, unlike enforcement by private parties (private enforcement), enforcement by regulators (public enforcement) is more effective. Jackson and Roe (2009) also find that public enforcement plays an important role.

To investigate this question, we examine whether accounting regulations and enforcement standards affect stock price crash risk. Crash risk is often used in the literature as an important measure of risk because it captures "tail risk" in portfolio management (e.g., Hutton et al., 2009: Robin and Zhang 2015). A stock price crash has more serious consequences when it occurs in the

\footnotetext{
${ }^{1}$ This argument has been empirically tested in recent studies (e.g., Chen et al., 2001; DeFond et al., 2015; Hutton et al., 2009; Jin and Myers, 2006; Kim et al., 2011a, 2011b; Kim and Zhang, 2016; Robin and Zhang, 2015).
} 
banking industry compared to non-finance sectors, as the crash of one bank's stock price can result in a systemic event in the entire financial system and the macroeconomy. ${ }^{2}$ The most recent example of this effect is the collapse of Lehman Brothers, which started a chain reaction in 2008. In the United States, the Federal Deposit Insurance Corporation closed several hundred failed banks after the 2008 financial crisis. Thus, understanding the effects of accounting regulations and enforcement on the stock price crash risk of banks is of importance to regulators and policy makers.

In addition, the banking industry provides a perfect testing ground to examine the effects of accounting regulations and enforcement mechanisms on stock price crash risk because it enables us to consider three important aspects of enforcement regulations. These are the regulations that enhance the effective operation of market discipline, strengthen bank supervision, and improve auditing quality in the banking industry. They are customized by regulatory agencies based on the unique features of a particular industry. The importance of these regulations in the banking industry is justified by the fact that they form two pillars of the Basel II and Basel III International Regulatory Frameworks (Basel Committee on Banking Supervision, 2006, 2011). In contrast, the literature on other industries (e.g., Burgstahler et al., 2006; Daske et al., 2008; Landsman et al., 2012; Leuz et al., 2003; Li, 2010) uses only the rule of law, which does not truly measure enforcement, per se, as a proxy for enforcement (Brown et al., 2014). More importantly, enforcement regulations in the banking industry include both public and private enforcement (Djankov et al., 2008; La Porta et al., 2006). Thus, our empirical tests show the effects of both the overall enforcement regulations and the individual components of these regulations.

\footnotetext{
${ }^{2}$ The measurement of stock price crash risk is very important in risk management contexts (Robin and Zhang, 2015). It is distinct from traditional risk measurements because it captures extreme downside price movement within the tail range of the distribution, and it can be difficult to be diversified (Ibragimov and Walden, 2007).
} 
To construct our sample, we obtain accounting regulation indicators from the World Bank surveys released in 2001, 2003, 2007, and 2011 to measure the situation of the accounting regulations of 1999, 2002, 2005, and 2010 (Barth et al., 2008, 2012). We employ these indicators to explain our measurements of stock price crash risk that are constructed based on 2000, 2003, 2006, and 2011 data. Following the bank regulation literature (e.g., Barth et al., 2006; Tadesse, 2006), the accounting regulation variable is defined as the sum of answers to six survey questions, such as whether banks are required to report off-balance-sheet items. We measure enforcement based on regulations that increase audit quality, strengthen market discipline, and depend on direct supervision. Based on this literature (Chen et al., 2001; DeFond et al., 2015; Hutton et al., 2009; Jin and Myers, 2006; Kim and Zhang, 2016; Kim et al., 2011a, 2011b; Robin and Zhang, 2015), we employ two measurements as proxies for stock price crash risk. The first measurement is the negative skewness of bank-specific returns; the second is the relative volatility of down- to upweek bank-specific returns. ${ }^{3}$

Employing a sample of observations that includes 37 countries, we provide robust evidence that stocks have less crash risk in countries with better accounting and enforcement regulations. The results suggest that stricter accounting and enforcement regulations could mitigate managers' bad-news-hiding behavior and reduce stock price crash risk (Chen et al., 2001; DeFond et al., 2015; Hutton et al., 2009; Jin and Myers, 2006; Kim and Zhang, 2016; Kim et al., 2011a, 2011b; Robin and Zhang, 2015). More importantly, we provide evidence that the effects of accounting

\footnotetext{
${ }^{3}$ We also construct two other stock price crash risk measures based on the literature (Chen et al., 2001; DeFond et al., 2015; Hutton et al., 2009; Jin and Myers, 2006; Kim and Zhang, 2016; Kim et al., 2011a, 2011b; Robin and Zhang, 2015) and use them as the robustness tests. The third measure is Crash Indicator, which equals 1 if at least one of a bank's bank-specific weekly returns in a given year is at least 3.09 standard deviations below the mean value. The fourth measure is Crash Frequency, which is constructed as the difference between the frequency of negative stock return outliers and the frequency of positive stock return outliers. Negative or positive stock return outliers are defined as the residual from Equation (1), which are lower than 1 percent of the distribution or higher than 99 percent of the distribution. This variable is presented in percentage. Higher values mean more stock price crash risk. We obtain the same conclusion in untabulated results.
} 
regulations are more significant in countries with stricter enforcement standards. The results suggest that accounting regulations and enforcement are complementary and that both determine the likelihood of a stock crash.

In our baseline test, our accounting regulations and enforcement variables include multiple dimensions of regulations. We also attempt to identify the effects of specific regulations. We find that most of the financial reporting regulations contribute to lower stock price crash risk. We also show that enforcement regulations that strengthen the effects of an external audit and direct supervision are more effective in determining stock price crash risk. Our results are robust even after including a series of control variables, for both large and small bank subsamples, for the subsample without U.S. banks, and when we employ alternative measures of enforcement.

We conduct a number of tests to address endogeneity concerns. First, we regress changes in stock price crash risk against changes in accounting regulations and enforcement as well as changes in other control variables. Second, we employ regional trends in accounting regulations and enforcement as our instrument to conduct an instrumental variable estimation. The results for change regression and instrumental variable estimation produce essentially the same inferences. Finally, we show that the effects of accounting and enforcement regulations are more significant in countries with high institutional quality. If our accounting regulations and enforcement variables capture only the omitted variables, we would not find such results. Thus, the results suggest that our baseline findings are less likely biased by endogeneity problems.

Our study is useful for several reasons. First, we contribute to the enforcement literature on business firms (e.g., Burgstahler et al., 2006; Daske et al., 2008; Landsman et al., 2012; Leuz et al., 2003; Li, 2010). Notably, the enforcement measurements of firms, such as rule of law, do not truly measure enforcement, per se (Brown et al., 2014). Different from these studies, we use 
the banking industry as a unique setting to test the effects of enforcement because enforcement in this highly regulated industry is customized by regulatory agencies and all industry-specific regulations. Our study could provide insight into the effects of enforcement regulations.

More importantly, bank regulatory and supervisory authorities, such as the International Monetary Fund and the World Bank, promote private enforcement regulations because they believe that these regulations play a more important role (La Porta et al., 2006). Jackson and Roe (2009), however, show that public enforcement regulations also are effective. Our measure of the enforcement regulations includes the regulations that strengthen both private and public enforcement. We demonstrate that the main effects of enforcement regulations on stock price crash risk are from enforcement regulations that strengthen external audit and direct supervision. Therefore, we contribute to the debate about the effectiveness of public and private enforcement.

Second, we contribute to the literature on the determinants of stock price crash risk (e.g., An and Zhang 2013; Francis et al., 2016; Hamm et al., 2012; Kim and Zhang, 2016; Kim et al., 2011a, 2011b; Kim et al., 2016; Robin and Zhang, 2015; for a comprehensive literature review of stock price crash risk, see Habib et al., 2018). ${ }^{4}$ Our findings suggest that accounting regulations and enforcement can significantly reduce stock price crash risk and that these two dimensions of regulations are complementary in affecting stock price crash risk. Thus, our results provide an additional perspective on how to reduce stock price crash risk and, thereby, to contribute to the

\footnotetext{
${ }^{4}$ The literature (An and Zhang 2013; Francis et al., 2016; Hamm et al., 2012; Kim and Zhang, 2016; Kim et al., 2011 a, 2011b; Kim et al., 2016; Robin and Zhang, 2015) has shown that tax avoidance activities, CFOs' option incentives, institutional ownership, management forecasts, accounting conservatism, audit quality, CEO overconfidence, and real earnings management are significantly associated with stock price crash risk. Related to our study, Haggard et al. (2008) find that business firms with more voluntary disclosure have lower stock crash risk. Hutton et al. (2009) show that business firms with more transparent financial statements are less likely to experience a stock crash. At the country level, Jin and Myers (2006) find that business firms' stocks are more likely to crash in countries with fewer auditors and poor financial statement disclosure. Bleck and Liu (2007) claim that, if a historical-cost accounting regime is more opaque, there is a greater stock price crash risk. DeFond et al. (2015) find that the adoption of International Financial Reporting Standards (IFRS) reduces stock price crash risk for non-financial firms and selectively influences financial firms.
} 
development of the entire economy. Further, DeFond et al. (2015) state that little is known about the determinants of crash risk for financial firms. Our study addresses this gap by using more precise variables for such firms than those of previous studies.

Finally, our study contributes to the literature on the effects of country-level bank accounting regulations. Tadesse (2006) shows that stricter bank disclosure regulations can decrease the likelihood of a financial crisis; and Barth et al. (2006) and Granja (2014) find that high-quality bank accounting regulations can enhance the stability of the financial system. Duru et al. (2018) claim that high-quality bank accounting regulations can increase financial statement informativeness; ${ }^{5}$ and Song (2017) shows that the quality of bank accounting regulations is positively related to stock returns and is negatively associated with stock volatility. We extend the literature by taking a new perspective, that of investigating whether stricter bank accounting regulations affect stock price crash risk. Our study also contributes to the literature on the impacts of bank-level disclosure. Our study complements that of Du et al. (2016), who examine the relationship between actual disclosures by individual banks and stock price crash risk, whereas we examine accounting regulations for banks at the country level.

The remainder of the paper is organized as follows. Section 2 presents the hypothesis development. Section 3 provides the data, and Section 4 describes the empirical results. Section 5 concludes.

\section{Hypothesis Development}

\footnotetext{
${ }^{5}$ We acknowledge that we use the same sample and the same measures of bank accounting regulations and enforcement standards as used by Duru et al. (2018). Our paper, however, considers stock price crash risk instead of informativeness.
} 
Our aim is to contribute to an understanding of how the quality of bank accounting regulations and enforcement mechanisms affect the stock price crash risk of commercial banks. Crash risk is often regarded as a proxy for "tail risk" in portfolio management and, hence, is one of the important risk measures for investors (Hutton et al., 2009; Robin and Zhang, 2015). Crash risk is more prevalent for commercial banks for a number of reasons. First, banks tend to be more opaque than non-financial firms, and opacity can intensify crash risk (Bleck and Liu, 2007). Banks' assets consist of a pool of loans to thousands of borrowers, which can be easily transformed, given that banks continuously generate new assets from the installments that they receive from the outstanding loans (Flannery, 1994). Morgan (2002) empirically tests the opacity of banks by showing that they are more likely than are non-financial firms to carry split ratings. Second, banks are highly leveraged and suffer from a structural asset-liability mismatch because they transform illiquid assets (loans) to liquid liabilities (demand deposits) (Diamond and Dybvig, 1983). As such, the structural fragility of commercial banks makes them subject to severe crash risk. Third, the crash risk in the banking system can impose substantial negative externalities to the economy, as banks are highly interconnected, and, as a result, a shock to one bank can be transmitted to other banks, which can cause a contagion in the entire market (Allen and Gale, 2000; Rochet and Tirole, 1996).

To achieve our aim, we test the following three hypotheses:

Hypothesis 1: Stricter bank accounting regulations reduce stock price crash risk.

Hypothesis 2: Stricter enforcement regulations reduce stock price crash risk.

Hypothesis 3: Enforcement mechanisms complement accounting regulations.

With regard to Hypothesis 1, the literature shows that stricter accounting regulations can restrain management from manipulation of financial reports (Barth et al., 2008) and thereby 
increase the reliability of disclosed information. Moreover, stricter regulations can push managers to provide more comprehensive information to outsiders (Bushman and Smith, 2001; Ewert and Wagenhofer, 2005), which leads to stronger market discipline and the timely intervention of outsiders to correct the flaws in the managerial system. We expect that stricter accounting regulations are particularly important for reducing stock price crash risk, given that managers have an incentive to hide bad news from the public to avoid receiving blame from stakeholders (Chen et al., 2001; DeFond et al., 2015; Hutton et al., 2009; Jin and Myers, 2006; Kim and Zhang, 2016; Kim et al., 2011a, 2011b; Robin and Zhang, 2015).

With reference to Hypothesis 2, stock price crash risk also depends on the effectiveness of the enforcement mechanisms of accounting standards. Compliance with accounting standards can be promoted via effective market discipline, direct supervision, and audit services. ${ }^{6}$ Enforcement regulations, which improve market discipline, not only can allow market participants to directly influence managers' behaviors but also can provide market signals to regulators to trigger regulatory intervention (e.g., Rochet, 2005; Stephanou, 2010). Enforcement regulations, which are related to direct supervision, require that financial reporting behaviors of managers be consistent with accounting regulations (Barth et al., 2004; Beck et al., 2006; Demirgüc-Kunt et al., 2008). ${ }^{7}$ Enforcement regulations, which strengthen audit services, can ensure financial reporting quality (Ball et al., 2003; Hope, 2003) ${ }^{8}$ These studies suggest that stricter compliance with accounting standards is expected to make a stock price crash less likely by confining excessive managerial risk-taking behavior, reducing the possibility of accounting manipulation, and improving the

\footnotetext{
${ }^{6}$ Brown et al. (2014) define enforcement as "the activities undertaken by independent bodies (monitoring, reviewing, educating, and sanctioning) to promote firms' compliance with accounting standards in their statutory financial statements."

${ }^{7}$ This argument has been shown empirically (e.g., Barth et al., 2004; Beck et al., 2006; Demirgüc-Kunt et al., 2008).

${ }^{8}$ Consistent with this notion, Francis et al. (2003) and Sami and Zhou (2008) find that a better audit environment is associated with superior financial reporting quality.
} 
quality of financial reports. Nevertheless, one may argue that regulations that increase private monitoring by external investors and auditors may not be able to impose severe punishments on wrongdoers. Regulators, who implement public enforcement, may not have enough information about the market (Jackson and Roe, 2009). Therefore, these enforcement regulations may not play an important role.

Regarding Hypothesis 3, we investigate whether enforcement mechanisms complement or substitute for accounting regulations in ameliorating stock price crash risk. There are two reasons why enforcement mechanisms complement accounting regulations. On the one hand, enforcement mechanisms play a crucial role because, without adequate enforcement, managers have no incentive to comply with accounting regulations (e.g., Burgstahler et al., 2006). ${ }^{9}$ On the other hand, the effectiveness of enforcement mechanisms depends on the quality of accounting regulations (e.g., Bushman and Williams, 2012; Demirgüc-Kunt et al., 2008; Tadesse, 2006). Thus, the influence of promulgating high-quality accounting regulations might be more significant in countries with stricter enforcement mechanisms. It is also possible that enforcement mechanisms and accounting regulations could be substitutes because they can both contain managers' badnews-hiding behaviors and increase the financial reporting quality (e.g., Hope, 2003; La Porta et al., 1998). Thus, the impact of establishing efficient accounting standards might be less significant in countries with stricter enforcement environments. Notably, the resolution of the competing views is an empirical question.

\section{Data}

\footnotetext{
${ }^{9}$ Consistent with this argument, the literature (e.g., Byard et al., 2011; Daske et al., 2008; Li, 2010) finds that the adoption of IFRS can reduce earnings management, decrease the cost of capital, increase stock liquidity, and improve firm valuations. These beneficial effects of IFRS are stronger in countries with better enforcement.
} 


\subsection{Variable Construction}

In this section, we describe the details of the variable construction, as seen in Table $1 . \mathrm{We}$ use the variables Accounting Regulation and Enforcement as measures of the following regulations: financial statement transparency and effectiveness of enforcement. Following the bank regulation literature (e.g., Barth et al., 2006; Tadesse, 2006), we obtain these indicators from the World Bank surveys. The variable Accounting Regulation is defined as the sum of answers to six survey questions, such as whether banks are required to report off-balance-sheet items (Barth et al., 2006). The variable Enforcement is equal to the sum of the three variables External Audit, External Monitoring, and Direct Supervision. The variable External Audit is equal to the sum of the answers to seven survey questions, such as whether supervisors can sue external auditors and force them to report directly to the regulators about the misconduct of bank managers. The variable External Monitoring is measured as the sum of the answers to five survey questions, such as whether the bank is rated. The variable Direct Supervision equals the sum of the answers to ten survey questions, such as whether the authorities can establish a new internal organizational structure of a bank.

\section{[Insert Table 1 about here]}

In this study, we employ two measures of crash risk. We follow the previous literature (e.g., Chen et al. 2001; DeFond et al., 2015; Kim et al. 2011a, 2011b) and use Negative Skewness as the first measure. Negative Skewness is defined as the negative of the third moment of bank-specific weekly returns, hereinafter $W i, t$, for each sample year, divided by the standard deviation of $W i, t$ raised to the power of three, i.e., minus the skewness of Wi,t. Because a negatively skewed distribution demonstrates the risk of extreme downside returns, we multiply the skewness by -1 for the ease of interpretation, e.g., a higher number indicates a greater crash risk. 
For our second measure of crash risk, we follow Chen et al. (2001) and Kim et al. (2011a) and use Down Up Volatility. To calculate this measure, we construct two subsamples. The first consists of the weeks with the Wi,t below the yearly average, hereafter down-weeks subsample. In the second subsample, we include the weeks with the $W i, t$ above the yearly average, hereafter upweeks subsample. Next, we calculate the standard deviation in each of the two subsamples. Then, we compute the ratio of the standard deviation in the down-weeks subsample to the standard deviation in the up-weeks subsample. Down Up Volatility is defined as the natural logarithm of this ratio. A higher value of this variable indicates a greater stock price crash risk.

We compute Wi,t as the natural logarithm of 1 plus the residual return of the below expanded market model, which is used in the previous studies (e.g., DeFond et al., 2015):

$$
\begin{aligned}
& R_{i, t}=\alpha_{i}+\beta_{1, i} R_{m, j, t}+\beta_{2, i}\left[R_{U S, t}+E x_{j, t}\right]+\beta_{3, i} R_{m, j, t-1}+\beta_{4, i}\left[R_{U S, t-1}+E x_{j, t-1}\right]+\beta_{5, i} R_{m, j, t-2}+ \\
& \beta_{6, i}\left[R_{U S, t-2}+E x_{j, t-2}\right]+\beta_{7, i} R_{m, j, t+1}+\beta_{8, i}\left[R_{U S, t+1}+E x_{j, t+1}\right]+\beta_{9, i} R_{m, j, t+2}+\beta_{10, i}\left[R_{U S, t+2}+\right. \\
& \left.E x_{j, t+2}\right]+\varepsilon_{i, t}
\end{aligned}
$$

The variable $R_{i, t}$ is equal to the Wednesday-to-Wednesday weekly return on stock $i$. We include only bank stocks with more than 30 weeks of data in a certain year and countries with at least two banks. The variable $R_{m, j, t}$ is equal to the weekly return of the market index in country $j$. The variable $R_{U S, t}$ equals the U.S. market return. The variable $E x_{j, t}$ is the change in the exchange rate between country $j$ and the United States. When we calculate the stock price crash risk measurements in the U.S. market, $\beta_{2, i}, \beta_{4, i}, \beta_{6, i}, \beta_{8, i}$, and $\beta_{10, i}$ are equal to zero.

We construct a series of country-level control variables based on data from the World Bank surveys. The variable Accounting Standards is equal to one if a country's accounting standard is IFRS or U.S. Generally Accepted Accounting Principles (GAAP), and zero otherwise. The 
variable Activity Restriction is constructed as the sum of the answers to three survey questions, such as whether banks are allowed to conduct business activities in the areas of real estate, insurance, and securities. Higher values indicate more restrictiveness. We employ the variable Capital Stringency to measure the extent of regulatory requirements of banks' capital.

We use the variable Democracy Quality to measure the level of democracy of a country, which is constructed as a revised combined polity score from the Polity IV Project. This polity score is widely used in political science research. ${ }^{10}$ This variable has a value from -10 to +10 . The lowest value, -10 , indicates that a country is strongly autocratic, and the highest value, +10 , indicates that a country is strongly democratic. We also obtain data from the World Development Indicator database to define the variables GDP Per Capita and GDP Growth, which measure economic development and growth, respectively.

We construct several control variables to measure stock characteristics based on data from the Datastream database, following the literature (Chen et al., 2001; DeFond et al., 2015; Hutton et al., 2009; Jin and Myers, 2006; Kim and Zhang, 2016; Kim et al., 2011a, 2011b; Robin and Zhang, 2015). The variable Share Turnover equals the difference in the average monthly bank stock share turnover between the current year and the prior year, in which monthly bank stock share turnover is defined as the monthly bank stock trading volume scaled by the number of bank stock shares outstanding during the month. The variable Deviation of Return is defined as the standard deviation of bank-specific weekly returns in a given year. The variable Mean of Return is equal to the mean value of bank-specific weekly returns in a given year.

We also construct a series of bank-level control variables based on data from the Bankscope database. The variable Bank Total Assets is equal to the logarithm of a bank's total

\footnotetext{
${ }^{10}$ More details can be found at http://www.systemicpeace.org/polity/polity4.htm
} 
assets. The variable STD ROA equals the standard deviation of a bank's return on investments (ROAs) over the prior five-year period. The variable Nonperforming Loan is defined as a bank's total problem loans divided by total assets. In addition, we construct the variable Analyst based on data from the IBES database, which is measured as the number of analysts with earnings forecasts for a certain bank.

\subsection{Sample and Summary Statistics}

To construct our sample, we obtain accounting regulation indicators from the World Bank surveys released in 2001, 2003, 2007, and 2011, which measure the situation of accounting regulations at the end of 1999, 2002, 2005, and 2010 (Barth et al., 2008, 2012). We employ these indicators to explain our measurements of stock price crash risk that are constructed based on 2000, 2003, 2006, and 2011 data. Our sample includes 1,711 observations from 37 countries across four years. The banks in the sample have more than 90 percent of the total assets of the global banking industry.

Panel A of Table 2 presents the number of banks, number of observations, and mean value of our accounting regulation variables by country. For example, the mean values of the variable Accounting Regulation have the highest value, 6, in South Korea and South Africa. The mean values of the variable Enforcement in the United States have the highest value, 20.375. The results indicate that the level of regulatory developments is different across countries. In untabulated results, the average values of the variable Accounting Regulation in 1999, 2002, 2005, and 2010 are 4.50,5.12, 5.40, and 5.53, respectively. The mean values of the variable Enforcement in 1999, 2002, 2005, and 2010 are $14.94,16.50,16.93$, and 17.17, respectively. Some of our data were collected in 1999 during the Asian Financial Crisis. The 2008 Global Financial Crisis also occurred 
in our sample period. The results show that the levels of accounting regulation and enforcement are increasing over time, as they might do in response to these two crises.

[Insert Table 2 about here]

Panel B of Table 2 shows summary statistics of variables for the entire sample. These results are consistent with the findings provided by the literature. The dependent variable Negative Skewness has a mean value of -0.275 and a standard deviation of 0.600 . The mean value of the other dependent variable, Down Up Volatility, is -0.141 and has a standard deviation of 0.500 . The key variable Accounting Regulation has a mean value of 5.193 and a standard deviation of 0.751 . The other key variable, Enforcement, has a mean value of 16.559 and a standard deviation of 2.806. The results suggest that there is sufficient variation in the variables employed in our empirical tests.

Panel $\mathrm{C}$ of Table 2 presents the correlations among our country-level variables. The correlation coefficient between Accounting Regulation and Enforcement is 0.189. The results suggest that a country with stronger accounting regulations might not have the same level of enforcement. We also find that these two key variables do not have strong correlations with our country-level control variables. Therefore, our estimations are not biased by multicollinearity problems.

\section{Results}

\subsection{Univariate Analysis}

Table 3 provides the results of our univariate analysis. Panels A and B show the results of the test of the effects of accounting regulations and enforcement on stock price crash risk. We create two subsamples. In the "high" subsample, as presented in the second column, the variables Accounting Regulation and Enforcement have values greater than the sample median. In the "low" 
subsample, as presented in the third column, the variables Accounting Regulation and Enforcement have values less than the sample median. We report the mean values of Negative Skewness and Down Up Volatility in these two subsamples and the differences in the last column.

[Insert Table 3 about here]

As reported in Panel A, the mean value of the variable Negative Skewness is equal to -0.314 (0.657) in countries with stricter (more lenient) regulations on the transparency of financial statement disclosure. Mean Negative Skewness is $-0.335(0.042)$ in countries with stricter (more lenient) regulations on the effectiveness of enforcement. We obtain the same results for Down Up Volatility, as seen in Panel B. The differences between these two subsamples as presented in the last column are all statistically significant at the $1 \%$ level. These results suggest that stocks have less crash risk in countries with stricter accounting and enforcement regulations.

As reported in Panels C and D, we further split our sample into four $2 \times 2$ groups based on the variables Accounting Regulation and Enforcement. As seen in Panel C, when a country has low enforcement standards, the difference in Negative Skewness between high and low accounting regulation regimes is 0.238 . In countries with high enforcement standards, however, the difference is 0.279 (statistically significant at the $10 \%$ level). We obtain the same results for Down Up Volatility, as seen in Panel D. The results suggest that the effects of accounting regulations on stock price crash risk are more pronounced in countries with high enforcement standards.

\subsection{Multivariate Analysis}

\subsubsection{Baseline Regressions}

To further examine the effects of accounting regulations and enforcement standards on stock price crash risk, we estimate the following baseline equation: 
Negative Skewness or Down Up Volatility $=\alpha+\beta_{1}$ Accounting Regulation $+\beta_{2}$

Enforcement $+\beta_{3}$ Control variables + Year effects $+\varepsilon$

We have two key variables: Accounting Regulation and Enforcement. We expect that these two variables have negative impacts on stock price crash risk. We include several country-level regulation, governance, and economic development variables. We control for Accounting Standards, Activity Restriction, Capital Stringency, Democracy Quality, GDP Per Capita, and GDP Growth. We expect that these variables might be negatively associated with stock price crash risk, following the literature (e.g., DeFond et al., 2015; Hutton et al., 2009; Jin and Myers, 2006; Kim and Zhang, 2016; Kim et al., 2011a, 2011b; Robin and Zhang, 2015).

We also include several bank characteristics. We control for the variables Bank Total Assets, STD ROA, Nonperforming Loan, and Analyst, which are related to banks' risk and information environments. Finally, we include certain variables to measure stock characteristics, such as Negative Skewness in the previous year, Share Turnover, Deviation of Return, and Mean of Return because these variables could be positively associated with stock price crash risk, following the prior literature (DeFond et al., 2015; Hutton et al., 2009; Jin and Myers, 2006; Kim and Zhang, 2016; Kim et al., 2011a, 2011b; Robin and Zhang, 2015). Compared to the dependent variables, all of the independent variables are measured in the previous year. In the estimations, we include year fixed effects and cluster by countries. The regression coefficients in all tables are unstandardized. For brevity, we do not report constants.

More importantly, we investigate whether the impact of accounting regulations is more significant in countries with stricter enforcement mechanisms. Different from Equation (2), we 
include an interaction term between Accounting Regulation and Enforcement. We expect the coefficient of this interaction term to be statistically negative. We estimate the following equation: Negative Skewness or Down Up Volatility $=\alpha+\beta_{1}$ Accounting Regulation $\times$ Enforcement $+\beta_{2}$ Accounting Regulation $+\beta_{3}$ Enforcement $+\beta_{4}$ Control variables + Year effects $+\varepsilon$

Columns (1) and (2) of Table 4 present the multivariate analysis of the influence of accounting and enforcement regulations on stock price risk, measured by Negative Skewness. In Column (1), we include country fixed effects but do not include country-level control variables. The coefficients of Accounting Regulation and Enforcement are all negative and statistically significant at the $1 \%$ level. These results are robust when we include country-level and bank-level control variables. The results suggest that stocks are less likely to crash in countries with better accounting and enforcement regulations. We also find that banks with higher non-performing loans and share turnover have a higher stock price crash risk. The coefficients of the variables Democracy Quality and Accounting Standards are negative and statistically significant at the 1\% level, implying that a superior institutional environment and higher accounting standards can reduce banks' risk-taking behaviors.

\section{[Insert Table 4 about here]}

Based on the results reported in Column (2) of Table 4, a one-standard-deviation increase in the variable Accounting Regulation (0.751) reduces the variable Negative Skewness by 0.204 $(0.272 \times 0.751)$. This would reduce the mean Negative Skewness from -0.275 to -0.479 and the median Negative Skewness from -0.376 to -0.580 . This shift is about $16.3 \%(0.204 / 1.250)$ of the range (1.250) between the 10th $(-0.853)$ and 90 th percentiles $(0.397)$. A one-standard-deviation 
increase in the variable Enforcement reduces the variable Negative Skewness by $0.191(0.068 \times$ 2.806). This would reduce the mean Negative Skewness from -0.275 to -0.466 and the median Negative Skewness from -0.376 to -0.567 . This shift is about 15.3 percent $(0.191 / 1.250)$ of the range (1.250) between the 10th (-0.853) and 90th percentiles (0.397). Thus, our findings also are economically significant.

Columns (4) and (5) of Table 4 present the multivariate analysis of the influence of accounting and enforcement regulations on bank stock price crash risk, measured by Down Up Volatility. In Column (4), we include country fixed effects because we do not include countrylevel control variables. The coefficients of Accounting Regulation and Enforcement are all negative and statistically significant at the $1 \%$ level. We reach the same conclusion when we include county-level and bank-level control variables. The results indicate that stocks have less crash risk in countries with stricter regulations on the effectiveness of enforcement and transparency of financial statement practices.

Based on the results reported in Column (5) of Table 4, a one-standard-deviation increase in the variable Accounting Regulation (0.751) reduces the variable Down Up Volatility by 0.240 $(0.319 \times 0.751)$. This would reduce the mean Down Up Volatility from -0.500 to -0.740 and the median Down Up Volatility from -0.223 to -0.463 . This shift is about 19.7 percent $(0.240 / 1.217)$ of the range (1.217) between the 10th $(-0.744)$ and 90 th percentiles $(0.473)$. A one-standarddeviation increase in the variable Enforcement (2.806) reduces the variable Down Up Volatility by $0.154(0.055 \times 2.806)$. This would reduce the mean Down Up Volatility from -0.500 to -0.654 and the median Down Up Volatility from -0.223 to -0.377 . This shift is about 12.7 percent $(0.154 / 1.217)$ of the range (1.217) between the 10th (-0.744) and 90th percentiles $(0.473)$. Thus, our findings also are economically significant. 
Columns (3) and (6) of Table 4 present a multivariate analysis of the influence of the interaction between accounting and enforcement regulations on stock price crash risk, measured by Negative Skewness and Down Up Volatility. The coefficients of the interaction term between Accounting Regulation and Enforcement are all negative and statistically significant at the 1\% or $5 \%$ level. Our results suggest that regulations for the transparency of financial statement disclosure might be less enforceable without stricter regulations for enforcement (Knechel et al., 2013). Stricter enforcement mechanisms should assure the quality of banks' financial disclosures by deterring earning misstatements. Thus, enforcement mechanisms and accounting regulations are complements in determining the likelihood of stock crashes.

In summary, our results suggest that stricter accounting regulations can push managers to provide more relevant information to outside investors (Bushman and Smith, 2001; Ewert and Wagenhofer, 2005). Stricter enforcement, such as market discipline, direct supervision, and audit services, might better monitor managers' opportunistic behaviors. Thus, stricter accounting regulations and enforcement could alleviate bad-news hoarding and decrease stock price crash risk.

\subsubsection{Individual Impacts of Accounting and Enforcement Regulations}

In the above empirical tests, our accounting regulations and enforcement variables include multiple dimensions of regulations. In this section, we identify specific regulations that affect stock price crash risk. As shown in Panel A of Table 5, we construct six dummy variables, SQ1, SQ2, SQ3, SQ4, SQ5, and SQ6, with the six survey questions, which are employed to construct the variable Accounting Regulation. The results show that five of the six dummy variables are negatively associated with stock price crash risk and that the first financial reporting requirement 
based on the first survey question $(S Q 1)$ is not significantly related to stock price crash risk. ${ }^{11}$ We also construct six interaction terms between these six dummy variables and Enforcement. The results still show that the five interaction terms with these five dummy variables are significant for determining stock price crash risk. In summary, most of these financial reporting regulations contribute to lower stock price crash risk.

\section{[Insert Table 5 about here]}

Similarly, as shown in Panel B of Table 5, we include three variables, External Audit, External Monitoring, and Direct Supervision, that are employed to create the variable Enforcement. The results show that the coefficients of External Audit and Direct Supervision are statistically significant and are negatively associated with stock price crash risk. We also construct three interaction terms between these three enforcement variables and Accounting Regulation. We obtain similar results, suggesting that enforcement regulations that strengthen the effects of external audits and direct supervision are more effective in determining stock price crash risk.

\subsubsection{Endogeneity Tests}

In this section, we attempt to address potential endogeneity problems. First, we conduct a change regression. As reported in Panel A of Table 6, we regress changes in stock price crash risk ( $\triangle$ Negative Skewness and $\triangle$ Down Up Volatility) against changes in accounting regulations and enforcement (AAccounting Regulation and $\Delta$ Enforcement) as well as changes in other control variables. ${ }^{12}$ We find that the coefficients of the variables AAccounting Regulation and

\footnotetext{
${ }^{11}$ The first survey question is, "Does accrued, though unpaid, interest/principal enter the income statement while the loan is still performing?" (Barth et al., 2006).

${ }^{12}$ The variables change between adjacent years that we have sampled, i.e., 2000 vs. 2003, 2003 vs. 2006, and 2006 vs. 2011. Therefore, there is a drop in the sample size because there is no adjacent-year observation for certain bankyear observations.
} 
Enforcement are significantly negative. The results suggest that changes in accounting regulations and enforcement standards drive changes in stock price crash risk. As shown in Columns (2) and (4), we find that the coefficients of the interaction term between $\triangle$ Accounting Regulation and $\Delta$ Enforcement also are significantly negative.

\section{[Insert Table 6 about here]}

Second, we conduct a two-stage instrumental variable estimation. Specifically, we define two instrument variables (Avg Accounting Regulation and Avg Enforcement) as the average values of accounting regulations (enforcement regulations) in an area where a bank is located. ${ }^{13} \mathrm{We}$ believe that region-level regulatory developments will definitely influence the regulation developments of each country. However, region-level regulatory developments will not directly affect the stock price crash risk of each bank. ${ }^{14}$

The results of the two-stage instrumental variables estimation are presented in Panel B of Table 6. In Columns (1) and (2), we report the results of the first-stage regression. In the first-stage regression, we regress Accounting Regulation (Enforcement) against our instrumental variables, Avg Accounting Regulation and Avg Enforcement, as well as other country-level variables and country and year dummy variables. The results show that the coefficients of our instrumental variables are significantly positive at the $1 \%$ level, suggesting that our instrumental variables are valid. In Columns (3) and (5), we report the results of the second-stage regressions. In the secondstage regressions, we include the predicted values of our accounting regulations and enforcement variables, Fitted Accounting Regulation and Fitted Enforcement, from the first stage. In Columns (4) and (6), we further add the interaction term between Fitted Accounting Regulation and Fitted

\footnotetext{
${ }^{13}$ When we calculate the average values, we exclude the bank's own country. We follow the World Bank's classification and define seven regions: East Asia and the Pacific; South Asia; Middle East and North Africa; Africa; Eastern Europe and Central Asia; Western Europe and other developed counties; and Latin America and the Caribbean. ${ }^{14}$ For the use of similar instrumental variables, please see Acemoglu et al. (2015).
} 
Enforcement. The results are similar to our findings using the baseline model, as presented in Table 4.

Finally, we add the interaction terms Accounting Regulation $\times$ Democracy Quality and Enforcement $\times$ Democracy Quality to our baseline model in Table 4 . We believe that, if our accounting regulations and enforcement variables capture the omitted variables, we should not find that the effects of these two variables are more significant in countries with high institutional quality. As shown in Panel C of Table 6, the coefficients of these two interaction terms are negative and statistically significant at the $1 \%$ level. The results suggest that our baseline results are less likely biased by endogeneity problems.

\subsubsection{Robustness Tests}

In this section, we estimate our baseline regression, using alternative specifications, as follows. First, as shown in the recent financial crisis, large banks have a greater possibility of being bailed out by the government. Thus, there might be structural differences between large banks and small banks. To ensure that our baseline results are not biased by bank size, we split our sample into a large bank subsample and a small bank subsample based on the median value of the variable Bank Total Assets each year. As shown in Table 7, we still obtain the same results for the subsamples as those in Table 4.

\section{[Insert Table 7 about here]}

Second, in our baseline test, we define our enforcement variable as the sum of External Audit, External Monitoring, and Direct Supervision. To ensure that our enforcement variable is a valid measurement, we employ two alternative measurements of enforcement standards: External Audit \& Direct Supervision and Direct Supervision. The variable External Audit \& Direct 
Supervision is equal to the sum of External Audit and Direct Supervision. As shown in Table 8, our results remain the same as in Table 4. Finally, we test whether our results still hold in the subsample without U.S. banks, as 41 percent of our sample banks are U.S. banks, and this might bias our estimations. We still obtain the same results as in Table 4 in the untabulated results.

[Insert Table 8 about here]

We also construct two other stock price crash-risk measures, following the literature (Chen et al., 2001; DeFond et al., 2015; Jin and Myers, 2006; Kim and Zhang, 2016; Kim et al., 2011a, 2011b; Robin and Zhang, 2015) and use them as the robustness tests. The third measure is Crash Indicator, which equals 1 if at least one of a bank's bank-specific weekly returns in a given year is at least 3.09 standard deviations below the mean value. The fourth measure is Crash Frequency, which is constructed as the difference between the frequency of negative stock return outliers and the frequency of positive stock return outliers. Negative or positive stock return outliers are defined as the residuals from Equation (1), which are lower than 1 percent of the distribution or higher than 99 percent of the distribution. This variable is presented as a percentage. Higher values mean more stock price crash risk. We still obtain the same results in the untabulated results.

Our data cover the years 2000, 2003, 2006, and 2011. These four years cover very different economic circumstances, including the Asian Financial Crisis and Global Financial Crisis, which may bias our estimation. To address this concern, we report the results in the subsample across years $(2000,2003,2006$, and 2011). We still obtain the same conclusion in untabulated results.

\section{Conclusion}

Regulatory agencies develop accounting regulations to improve financial reporting quality and to reduce information risk for external investors (Bushman and Smith, 2001). Enforcement of 
accounting regulations is also important because the benefits of adopting high-quality accounting regulations will be realized when we establish an effectiveness enforcement mechanism (Committee of European Securities Regulators, 2003; Securities and Exchange Commission, 2000). Employing a sample that includes major banks from 37 countries as a unique testing ground, we find that stocks are less likely to crash in countries with better enforcement mechanisms and accounting regulations for banks. More importantly, we provide evidence that the impact of bank accounting regulations is more significant in countries with stricter bank enforcement standards. Thus, enforcement standards and accounting regulations are complements, and both determine the likelihood of stock price crashes. We also find that the main channels for enforcement standards and accounting regulations to affect stock price crash risk are regulations that strengthen information disclosure and improve the effects of direct supervision and external auditors.

Our findings have significant policy implications. The information that we provide could be used to help develop more effective accounting regulations and enforcement mechanisms. For example, to increase transparency and financial stability, regulators could increase strictness in either enforcement mechanisms or disclosure requirements. The effects are more significant when the strictness of both accounting regulations and enforcement are increased. In addition, regulations could strengthen information disclosure and improve the effects of direct supervision and external auditors.

Similar to nearly every study in this area, our results are associational rather than causal. Future research may examine the causality of the relationship between these regulations and stock price crash risk. Future research also could investigate how accounting regulations and enforcement standards determine accounting conservatism. Another avenue is to examine how 
accounting regulations and enforcement mechanisms help to increase stock price informativeness. We leave these potential research areas for further study. 


\section{References}

Acemoglu, D., Naidu, S., Restrepo, P., Robinson, J.A., 2015. Democracy does cause growth. NBER Working Paper No. 20004.

Allen, F., Gale, D., 2000. Financial contagion. J. Political Econ.108(1), 1-33.

An, H., Zhang, T., 2013. Stock price synchronicity, crash risk, and institutional investors. J. Corporate Finance 21, 1-15.

Ball, R., 2009. Market and political/regulatory perspective on the recent accounting scandals. J. Account. Res. 47(2), 277-323.

Ball, R., Robin, A., Wu, J.S., 2003. Incentives versus standards: properties of accounting income in four east Asian countries. J. Account. Econ. 36(1-3), 235-270.

Barth, J.R., Caprio, G., Levine, R., 2004. Regulation and supervision: what works best? J. Financial Intermediation 13, 205-248.

Barth, J.R., Caprio, G., Levine, R., 2006. Rethinking bank regulation: till angels govern. Cambridge University Press, Cambridge.

Barth, J.R., Caprio, G., Levine, R., 2008. Bank regulations are changing: for better or worse? Comparative Econ. Stud. 50, 537-563.

Barth, J.R., Caprio, G., Levine, R., 2012. The evolution and impact of bank regulations. World Bank Policy Research Working Paper No. 6288.

Basel Committee on Banking Supervision (Basel). 2006. Core principles for effective banking supervision. www.bis.org/publ/bcbs129.pdf.

Basel Committee on Banking Supervision (Basel). 2011. Basel III: a global regulatory framework for more resilient banks and banking systems. http://www.bis.org/publ/bcbs189.htm.

Bleck, A., Liu, X., 2007. Market transparency and the accounting regime. J. Account. Res. 45(2), 229-256.

Beck, T., Demirgüc-Kunt, A., Levine, R., 2006. Bank supervision and corruption in lending. J. Monetary Econ. 53, 2131-2163.

Brown, P., Preiato, J., Tarca, A., 2014. Measuring country differences in enforcement of accounting standards: an audit and enforcement proxy. J. Bus. Finance Account. 41, 1-52.

Burgstahler, D., Hail, L., Leuz, C., 2006. The importance of reporting incentives: earnings management in european private and public firms. Account. Rev. 81(5), 983-1016. 
Bushman, R.M., Smith, A.J., 2001. Financial accounting information and corporate governance. J. Account. Econ. 32(1), 237-333.

Bushman, R.M., Williams, C.D., 2012. Accounting discretion, loan loss provisioning, and discipline of banks' risk-taking. J. Account. Econ. 54, 1-18.

Byard, D., Li, Y., Yu, Y., 2011. The effect of mandatory IFRS adoption on financial analysts' information environment. J. Account. Res. 49(1), 69-95.

Chen, J., Hong, H., Stein, J., 2001. Forecasting crashes: trading volume, past returns, and conditional skewness in stock prices. J. Financial Econ. 61(3), 345-381.

Committee of European Securities Regulators (CESR), 2003. Standard No. 1 on financial information: enforcement of standards on financial information in Europe. CESR 03/073. March. Available at https:/www.esma.europa.eu/document/standard-no-1-financialinformation.

Daske, H., Hail, L., Leuz, C., Verdi, R., 2008. Mandatory IFRS reporting around the world: early evidence on the economic consequences. J. Account. Res. 46(5), 1085-1142.

DeFond, M. L., Hung, M.Y., Li, S.Q., Li., Y.H., 2015. Does mandatory IFRS adoption affect crash risk? Account. Rev. 90(1), 265-299.

Demirgüc-Kunt, A., Detragiache, E., Tressel. T., 2008. Banking on the principles: compliance with Basel core principles and bank soundness. J. Financial Intermediation 17, 511-542.

Diamond, D.W., Dybvig, P.H., 1983. Bank runs, deposit insurance, and liquidity. J. Political Econ. 91, 401-419.

Djankov, S., La Porta, R., Lopez-de-Silanes, F., Shleifer, A. 2008. The law and economics of selfdealing. J. Financial Econ. 88(3), 430-465.

Du, C., Song, L., Wu, J., 2016. Bank accounting disclosure, information content in stock prices, and stock crash risk. Pacific Account. Rev. 28(3), 260-278.

Duru, A., Hasan, I., Song, L., Zhao, Y.J., 2018. Bank accounting regulations, enforcement mechanisms, and financial statement informativeness: cross-country evidence. Account. Bus. Res. Forthcoming.

Ewert, R., Wagenhofer, A., 2005. Economic effects of tightening accounting standards to restrict earnings management. Account. Rev. 80 (4), 1101-1124.

Flannery, M.J., 1994. Debt maturity and the deadweight cost of leverage: optimally financing banking firms. American Econ. Rev. 84 (1), 320-331. 
Francis, B., Hasan, I., Li, L.X., 2016. Abnormal real operations, real earnings management, and subsequent crashes in stock prices. Rev. Quant. Finance and Account. 46 (2), 217-260.

Francis, J.R., Khurana, I.K., Pereira, R. 2003. The role of accounting and auditing in corporate governance and the development of financial markets around the world. Asia-Pacific J. Account. Econ. 10(1), 1-30.

Granja, J. 2014. Disclosure Regulation in Commercial Banking: Lessons from the National Banking Era. Northwest University Working Paper.

Habib, A., Hasan, M.M., Jiang, H.Y., 2018. Stock price crash risk: review of the empirical literature. Account. Finance 58(S1), 211-251.

Hamm, S.J.W., Jeffrey Ng, T.Y., Li, E.X., 2012. Management earnings guidance and stock price crash risk. Working paper, Ohio State University.

Hope, O.K., 2003. Disclosure practices, enforcement of accounting standards, and analysts' forecast accuracy: an international study. J. Account. Res. 41(2), 235-272.

Haggard, K.S., Martin, X.M., Pereira, R., 2008. Does voluntary disclosure improve stock price informativeness? Financial Management 37(4), 747-768.

Hutton, A.P., Marcus, A.J., Tehranian, H., 2009. Opaque financial reports, $\mathrm{R}^{2}$, and crash risk. J. Financial Econ. 94(1):67-86.

Ibragimov, R., Walden, J., 2007. The limits of diversification when losses may be large. J. Bank. Finance 31(8), 2551-2569.

Jackson, H., Roe, M., 2009. Public and private enforcement of securities laws: resource-based evidence. J. Financial Econ. 93(2), 207-238.

Jin L., Myers, S.C., 2006. $\mathrm{R}^{2}$ around the world: new theory and new tests. J. Financial Econ. 79, 257-292.

Knechel, R.W., Krishna, G., Pevzner, M., Shefchik, L., Velury, U., 2013. Audit quality: insights from the academic literature. Auditing 32 (Supplement 1), 385-421.

Kim, J.B., Li, Y.H., Zhang, L.D., 2011a. Corporate tax avoidance and stock price crash risk: firmlevel analysis. J. Financial Econ. 100(3), 639-662.

Kim, J.B., Li, Y.H., Zhang, L.D., 2011b. CFOs versus CEOs: equity incentives and crashes. J. Financial Econ. 101(3), 713-730.

Kim, J.B., Zhang, L.D., 2016. Accounting conservatism and stock price crash risk: firm-level evidence. Contemp. Account. Res. 33(1), 412-441. 
Kim, J.B., Wang, Z., Zhang, L.D., 2016. CEO overconfidence and stock price crash risk. Contemp. Account. Res. 33(4), 1720-1749.

Kothari, S.P., Shu, S., Wysocki, P.D., 2009. Do managers withhold bad news? J. Account. Res. 33(4), 1720-1749.

Landsman, W.R., Maydew, E.L., Thornock, J.R., 2012. The information content of annual earnings announcements and mandatory adoption of IFRS. J. Account. Econ. 53(1), 34-54.

La Porta, R., Lopez-de-Silanes, F., Shleifer, A., Vishny, R., 1998. Law and finance. J. Political Econ. 106 (6), 1113-1155.

La Porta, R., Lopez-de-Silanes, F., Shleifer, A., 2006. What works in securities laws? J. Finance 61(1), 1-32.

Leuz, C., Nanda, D., Wysocki, P., 2003. Earnings management and investor protection: an international comparison. J. Financial Econ. 69, 505-527.

Li, S., 2010. Does mandatory adoption of international financial reporting standards in the european union reduce the cost of equity capital? Account. Rev. 85(2), 607-636.

Morgan, D.P., 2002. Rating banks: risk and uncertainty in an opaque industry. American Econ. Rev. 92(4), 874-888.

Robin, A.J., Zhang, H., 2015. Do industry-specialist auditors influence stock price crash risk? AUDITING 34(3), 47-79.

Rochet, J.C., 2005. Prudential policy. Monetary and Economic Studies (Special Edition) October, 93-119.

Rochet, J.C., Tirole. J., 1996. Interbank lending and systemic risk. J. Money Credit Bank. 28 (4), 733-762.

Sami, H., Zhou, H., 2008. Do auditing standards improve the accounting disclosure and information environment of public companies? evidence from the emerging markets in China. International J. Account. 43(2), 139-169.

Securities and Exchange Commission. (SEC). 2000. The concept release on international accounting standards. Available at http://www.sec.gov/rules/concept/34-42430.htm. Accessed October 15, 2001.

Song, L., 2017. The effects of accounting regulations on stock valuation and volatility: evidence from the banking industry. J. International Financial Management Account. 28(2), 205-229.

Stephanou, C. 2010. Rethinking market discipline in banking: lessons from the financial crisis. Policy Research Working Paper 5227, the World Bank. 
Tadesse, S., 2006. The economic value of regulated disclosure: evidence from the banking sector. J. Account. Public Policy 25, 32-70. 


\section{Table 1. Variable Definitions}

$\begin{array}{ll}\text { Variable } & \text { Description }\end{array}$

\section{Dependent variables}

Negative Skewness

Down Up Volatility

Accounting regulation variables

Accounting Regulation

External Audit

External Monitoring

Direct Supervision
The negative skewness of bank-specific weekly returns. Bank-specific weekly return is equal to the natural logarithm of the sum between the residual from Equation (1) and 1.

Log (the standard deviation of bank-specific returns in down weeks divided by the standard deviation of bank-specific weekly returns in up weeks).

"The sum of assigned values of the questions as below (by default, 1 if it equals "yes" and 0 otherwise.): (1) Does accrued, though unpaid interest/principal enter the income statement while the loan is still performing? (2) Are financial institutions required to produce consolidated accounts covering all bank and any nonbank financial subsidiaries? (3) Are off-balance sheet items disclosed to the public? (4) Must banks disclose their risk management procedures to the public? (5) Are bank directors legally liable if information disclosed is erroneous or misleading? (6) Does accrued, though unpaid interest/principal enter the income statement while the loan is still nonperforming? ( 1 if it is No; 0 otherwise.) Higher values indicate greater financial statement transparency." Barth et al., (2006).

"The sum of assigned values of the questions as below (by default, 1 if it equals "yes" and 0 otherwise.): (1) Is an external audit a compulsory obligation for banks? (2) Are specific requirements for the extent or nature of the audit spelled out? (3) Are auditors licensed or certified? (4) Do supervisors get a copy of the auditor's report? (5) Does the supervisory agency have the right to meet with external auditors to discuss their report without the approval of the bank? (6) Are auditors required by law to communicate directly to the supervisory agency any presumed involvement of bank directors or senior managers in illicit activities, fraud, or insider abuse? (7) Can supervisors take legal action against external auditors for negligence? Higher values indicate greater strength of external audit." Barth et al., (2006).

"The sum of assigned values of the questions as below (by default, 1 if it equals "yes" and 0 otherwise.): (1) What percentage of the top ten banks are rated by international credit rating agencies (e.g., Moody's, Standard and Poor)? (1 if it equals $100 \%$; 0 otherwise.) (2) How many of the top ten banks are rated by domestic credit rating agencies? (1 if it equals $100 \%$; 0 otherwise.) (3) a. Is there an explicit deposit insurance protection system? b. Were depositors wholly compensated (to the extent of legal protection) the last time a bank failed? ( 1 if $\mathrm{a}=0$ and/or $\mathrm{b}=0,0$ otherwise.) (4) a. Is subordinated debt allowable as part of capital? b. Is subordinated debt required as part of capital? (1 if a or b equals "yes") (5) Are bank regulators/supervisors required to make public formal enforcement actions, which include cease and desist orders and written agreements between a bank regulatory/supervisory body and a banking organization? Higher values indicate greater external monitoring." Barth et al., (2006).

"The sum of assigned values of the questions as below (by default, 1 if it equals "yes" and 0 otherwise.): (1) Can the supervisory authority force a bank to change its internal organizational structure? (2) Are off-balance sheet items disclosed to supervisors? (3) Can the supervisory agency order the bank's directors or management to constitute provisions to cover actual or potential losses? (4) Can the supervisory agency suspend the directors' decision to distribute dividends? (5) Can the supervisory agency suspend the directors' decision to distribute Bonuses? (6) Can the supervisory agency suspend the directors' decision to distribute management fees? (7) Who can legally declare - such that this 
Enforcement

External Audit \& Direct Supervision declaration supersedes the some of the rights of shareholders - that a bank is insolvent: bank supervisor, court, deposit insurance agency, bank restructuring, asset management agency or other. (bank supervisor $=1$; deposit insurance agency $=0.5$; bank restructuring or asset management agency $=0.5 ; 0$ otherwise.) (8) According to the Banking Law, who has authority to intervene - that is, suspend some or all ownership rights- a problem bank? Bank supervisor, court, deposits insurance agency, bank restructuring, asset management agency or other. (bank supervisor $=1$; deposit insurance agency $=0.5$; bank restructuring or asset management agency $=0.5$; 0 otherwise.) (9) Regarding bank restructuring and reorganization, can the supervisory agency or any other government agency supersede shareholder rights? Bank supervisor, court, deposits insurance agency, bank restructuring, asset management agency or other. (Bank supervisor $=1$; deposit insurance agency $=0.5$; bank restructuring or asset management agency $=0.5$; 0 otherwise.) (10) Regarding bank restructuring and reorganization, can the supervisory agency or any other government agency remove and replace management? Bank supervisor, court, deposits insurance agency, bank restructuring, asset management agency or other. (Bank supervisor $=1$; deposit insurance agency $=0.5$; bank restructuring or asset management agency $=0.5 ; 0$ otherwise.) (11) Regarding bank restructuring and reorganization, can the supervisory agency or any other government agency remove and replace directors? Bank supervisor, court, deposits insurance agency, bank restructuring, asset management agency or other. (bank supervisor $=1$; deposit insurance agency $=0.5$; bank restructuring or asset management agency $=0.5 ; 0$ otherwise.) Higher values indicate greater direct supervision." Barth et al., (2006).

External Audit + External Monitoring + Direct Supervision

External Audit + Direct Supervision

\section{Control variables}

Accounting Standards

Activity Restriction

Capital Stringency

Democracy Quality
"The assigned values of the questions as below (by default, 1 if it equals "yes" and 0 otherwise.): Are accounting practices for banks in accordance with International Accounting Standards or U.S. Generally Accepted Accounting Standards? Higher values indicate better accounting standard.” Barth et al., (2006).

"The sum of assigned values of the questions about whether banks can engage in securities, insurance, and real estate activities. Unrestricted = 1 = full range of activities can be conducted directly in the bank; Permitted $=2$ = full range of activities can be conducted, but some or all must be conducted in subsidiaries; Restricted $=3=$ less than full range of activities can be conducted in the bank or subsidiaries; and Prohibited $=4$ = the activity cannot be conducted in either the bank or subsidiaries. Higher values indicate greater restrictiveness." Barth et al., (2006).

"The sum of dummy variables or assigned values of questions (by default, 1 if it equals "yes" and 0 otherwise.): (1) Is the minimum capitalasset ratio requirement risk weighted in line with the Basel I guidelines? (2) Does the minimum ratio vary as a function of an individual bank's credit risk? (3) Does the minimum ratio vary as a function of market risk? (4) Before minimum capital adequacy is determined, which of the following are deducted from the book value of capital? Market value of loan losses not realized in accounting books? (5) Unrealized losses in securities portfolios? (6) Unrealized foreign exchange losses? (7) Is the faction of revaluation gains allowed as part of capital less than 0.75 ? (8) Are the sources of funds to be used as capital verified by the regulatory/supervisory authorities? (9) Can the initial disbursement of subsequent injections of capital be done with assets other than cash or government securities? ( 1 if it equals "no" and 0 otherwise.) (10) Can initial disbursement of capital be done with borrowed funds? (1 if it equals "no" and 0 otherwise.)" Barth et al. (2006).

Revised combined polity score. 


\begin{tabular}{ll}
\hline GDP Per Capita & Log of GDP per capita. \\
GDP Growth & GDP growth. \\
Share Turnover & $\begin{array}{l}\text { The difference in the average monthly bank stock share turnover between } \\
\text { the current year and the prior year. The monthly bank stock share } \\
\text { turnover is constructed as the monthly bank stock trading volume divided } \\
\text { by the number of stock shares outstanding. }\end{array}$ \\
Deviation of Return & $\begin{array}{l}\text { The standard deviation of bank-specific weekly returns in a given year. } \\
\text { Mean of Return }\end{array}$ \\
Bank Total Assets & Log (total assets). \\
STD ROA & $\begin{array}{l}\text { The standard deviation of return on assets for a bank over the prior five- } \\
\text { year period. }\end{array}$ \\
Nonperforming Loan & Total problem loans divided by total assets. \\
Analyst & The number of analysts with earnings forecasts for a bank.
\end{tabular}




\section{Table 2. Summary statistics}

\begin{tabular}{|c|c|c|c|c|}
\hline Country & No. of Banks & No. of Observations & Accounting Regulation & Enforcement \\
\hline Australia & 11 & 21 & 5.500 & 18.500 \\
\hline Austria & 3 & 5 & 4.333 & 16.000 \\
\hline Belgium & 4 & 10 & 5.000 & 16.000 \\
\hline Brazil & 13 & 42 & 5.000 & 19.000 \\
\hline Canada & 8 & 24 & 5.500 & 13.500 \\
\hline Chile & 5 & 18 & 5.250 & 17.333 \\
\hline Colombia & 6 & 16 & 5.000 & 18.333 \\
\hline Denmark & 40 & 123 & 5.500 & 15.667 \\
\hline Finland & 2 & 7 & 5.500 & 12.500 \\
\hline France & 18 & 54 & 4.750 & 13.750 \\
\hline Germany & 9 & 27 & 4.333 & 15.000 \\
\hline Greece & 10 & 22 & 5.000 & 15.250 \\
\hline Hong Kong & 10 & 17 & 5.333 & 16.333 \\
\hline India & 17 & 19 & 4.667 & 16.000 \\
\hline Indonesia & 11 & 12 & 5.000 & 19.250 \\
\hline Ireland & 3 & 6 & 5.333 & 16.250 \\
\hline Italy & 20 & 32 & 5.333 & 13.333 \\
\hline Japan & 84 & 166 & 4.667 & 18.500 \\
\hline Korea & 15 & 30 & 6.000 & 16.500 \\
\hline Malaysia & 11 & 39 & 5.500 & 17.000 \\
\hline Mexico & 4 & 12 & 5.250 & 16.667 \\
\hline Netherlands & 2 & 4 & 5.000 & 15.000 \\
\hline Norway & 13 & 13 & 4.000 & 15.250 \\
\hline Pakistan & 14 & 39 & 5.667 & 19.500 \\
\hline Peru & 6 & 20 & 5.250 & 17.750 \\
\hline Philippines & 13 & 18 & 5.667 & 16.667 \\
\hline Poland & 8 & 12 & 5.000 & 16.667 \\
\hline Portugal & 5 & 9 & 5.000 & 19.000 \\
\hline Singapore & 3 & 3 & 5.500 & 19.500 \\
\hline South Africa & 7 & 12 & 6.000 & 13.500 \\
\hline Spain & 14 & 25 & 5.500 & 16.750 \\
\hline Sweden & 4 & 9 & 4.667 & 11.500 \\
\hline Taiwan & 10 & 39 & 5.250 & 19.000 \\
\hline Thailand & 9 & 17 & 5.333 & 18.333 \\
\hline Turkey & 9 & 16 & 5.000 & 17.500 \\
\hline United Kingdom & 9 & 18 & 5.250 & 15.500 \\
\hline United States & 301 & 873 & 5.250 & 20.375 \\
\hline
\end{tabular}

Panel A of Table 2 presents the number of banks, number of observations, and average value of accounting regulations and enforcement standards by country. We present the definitions of all of the variables in Table 1. 


\begin{tabular}{lccccc}
\hline Panel B & Mean & Std. Dev. & 10th Pctl. & 50th Pctl. & 90 th Pctl. \\
\hline Variable & -0.275 & 0.600 & -0.853 & -0.376 & 0.397 \\
Negative Skewness & -0.141 & 0.500 & -0.744 & -0.223 & 0.473 \\
Down Up Volatility & 5.193 & 0.751 & 4.000 & 5.000 & 6.000 \\
Accounting Regulation & 16.559 & 2.806 & 13.000 & 17.000 & 20.000 \\
Enforcement & 0.702 & 0.460 & 0.000 & 1.000 & 1.000 \\
Accounting Standards & 6.879 & 1.984 & 4.000 & 7.000 & 10.000 \\
Activity Restriction & 6.306 & 1.885 & 4.000 & 6.000 & 9.000 \\
Capital Stringency & 6.553 & 3.045 & 5.000 & 5.000 & 9.000 \\
Democracy Quality & 7.811 & 1.201 & 6.396 & 7.974 & 9.170 \\
GDP Per Capita & 7.392 & 1.762 & 5.379 & 7.575 & 9.161 \\
GDP Growth & -0.249 & 0.598 & -1.044 & -0.156 & 0.414 \\
Prior Year Negative Skewness & 0.011 & 0.125 & -0.006 & -0.006 & 0.004 \\
Share Turnover & 0.049 & 0.316 & 0.000 & 0.003 & 0.044 \\
Deviation of Return & -0.291 & 0.356 & -0.399 & -0.387 & -0.187 \\
Mean of Return & 15.245 & 1.968 & 12.834 & 15.052 & 17.893 \\
Bank Total Assets & 0.031 & 0.003 & 0.030 & 0.030 & 0.031 \\
STD ROA & 0.013 & 0.021 & 0.001 & 0.004 & 0.035 \\
Nonperforming Loan & 6.481 & 2.889 & 3.000 & 6.000 & 11.000 \\
Analyst & & & & & \\
\hline
\end{tabular}

Panel B of Table 2 presents the summary statistics for the entire sample. We present the definitions of all of the variables in Table 1. Our sample includes 1,711 observations from 37 countries across four years. 
Panel C

\begin{tabular}{|c|c|c|c|c|c|c|c|c|}
\hline & $\begin{array}{l}\text { Accounting } \\
\text { Regulation }\end{array}$ & Enforcement & $\begin{array}{c}\text { Accounting } \\
\text { Standards }\end{array}$ & $\begin{array}{c}\text { Activity } \\
\text { Restriction }\end{array}$ & $\begin{array}{c}\text { Capital } \\
\text { Stringency }\end{array}$ & Democracy Quality & $\begin{array}{c}\text { GDP } \\
\text { Per Capita }\end{array}$ & $\begin{array}{c}\text { GDP } \\
\text { Growth }\end{array}$ \\
\hline Enforcement & $\begin{array}{l}0.189^{*} \\
(0.068)\end{array}$ & 1.000 & & & & & & \\
\hline $\begin{array}{l}\text { Accounting } \\
\text { Standards }\end{array}$ & $0.186^{*}$ & 0.186 & 1.000 & & & & & \\
\hline Activity & $(0.091)$ & $(0.108)$ & & & & & & \\
\hline Restriction & $\begin{array}{c}0.091 \\
(0.350)\end{array}$ & $\begin{array}{c}0.380 * * * \\
(0.000)\end{array}$ & $\begin{array}{l}-0.125 \\
(0.263)\end{array}$ & 1.000 & & & & \\
\hline $\begin{array}{l}\text { Capital } \\
\text { Stringency }\end{array}$ & 0.033 & $0.182 *$ & $0.211^{*}$ & -0.004 & 1.000 & & & \\
\hline Institutional & $(0.745)$ & $(0.095)$ & $(0.071)$ & $(0.971)$ & & & & \\
\hline Quality & $\begin{array}{c}0.194 * * \\
(0.049)\end{array}$ & $\begin{array}{c}0.269 * * \\
(0.011)\end{array}$ & $\begin{array}{c}0.110 \\
(0.333)\end{array}$ & $\begin{array}{c}0.297 * * * \\
(0.003)\end{array}$ & $\begin{array}{l}-0.012 \\
(0.909)\end{array}$ & 1.000 & & \\
\hline $\begin{array}{l}\text { GDP } \\
\text { Per Capita }\end{array}$ & 0.105 & $0.288 * * *$ & 0.056 & $\left(0.376^{* * *}\right.$ & -0.013 & $0.498 * * *$ & 1.000 & \\
\hline $\begin{array}{l}\text { GDP } \\
\text { Growth }\end{array}$ & $\begin{array}{c}(0.277) \\
0.019 \\
(0.849)\end{array}$ & $\begin{array}{c}0.114 \\
(0.272) \\
\end{array}$ & $\begin{array}{l}-0.023 \\
(0.834)\end{array}$ & $\begin{array}{l}-0.072 \\
(0.463)\end{array}$ & $\begin{array}{c}0.044 \\
(0.666) \\
\end{array}$ & $\begin{array}{l}-0.132 \\
(0.183)\end{array}$ & $\begin{array}{l}-0.058 \\
(0.547)\end{array}$ & 1.000 \\
\hline
\end{tabular}

Panel C of Table 2 presents the correlation statistics of our country-level variables. We present the definitions of all of the variables in Table 1. Our sample includes 1,711 observations from 37 countries across four years. 


\section{Table 3. Univariate Analysis for Stock Price Crash Risk}

Panel A

\begin{tabular}{l|ccc}
\hline & \multicolumn{3}{|c}{ Negative Skewness } \\
\hline Partitioning Variables & High & Low & Low-High \\
\hline Accounting Regulation & -0.314 & 0.657 & $0.972^{* * *}$ \\
Enforcement & -0.335 & 0.042 & $0.378^{* * *}$ \\
\hline
\end{tabular}

Panel B

\begin{tabular}{l|ccc}
\hline & \multicolumn{3}{|c}{ Down Up Volatility } \\
\hline Partitioning Variables & High & Low & Low-High \\
\hline Accounting Regulation & -0.181 & 0.796 & $0.977^{* * *}$ \\
Enforcement & -0.205 & 0.191 & $0.396^{* * *}$ \\
\hline
\end{tabular}

$\underline{\text { Panel C }}$

\begin{tabular}{l|ccc}
\hline Negative Skewness & High Enforcement & Low Enforcement & $\begin{array}{c}\text { Low-High } \\
\text { (Enforcement) }\end{array}$ \\
\hline High Accounting Regulation & -0.422 & 0.121 & $0.543^{* *}$ \\
Low Accounting Regulation & -0.143 & 0.359 & $0.502^{* * *}$ \\
Low-High (Accounting Regulation) & $0.279^{* *}$ & $0.238^{* * *}$ & $0.041^{*}$ \\
\hline
\end{tabular}

$\underline{\text { Panel D }}$

\begin{tabular}{l|ccc}
\hline Down Up Volatility & High Enforcement & Low Enforcement & $\begin{array}{c}\text { Low-High } \\
\text { (Enforcement) }\end{array}$ \\
\hline High Accounting Regulation & -0.611 & -0.123 & $0.488^{* * *}$ \\
Low Accounting Regulation & -0.035 & 0.397 & $0.432^{* *}$ \\
Low-High (Accounting Regulation) & $0.576^{* * *}$ & $0.520^{* *}$ & $0.056^{*}$ \\
\hline
\end{tabular}

Table 3 presents the results of the univariate analysis. We use *,**, and $* * *$ to indicate $10 \%, 5 \%$, and $1 \%$ significance levels, respectively. We present the definitions of all of the variables in Table 1. 
Table 4. Effects of Accounting and Enforcement Regulations

\begin{tabular}{|c|c|c|c|c|c|c|}
\hline \multirow[t]{2}{*}{ Dependent Variable } & \multicolumn{3}{|c|}{ Negative Skewness } & \multicolumn{3}{|c|}{ Down Up Volatility } \\
\hline & $(1)$ & $(2)$ & (3) & (4) & (5) & $(6)$ \\
\hline \multirow[t]{2}{*}{ Accounting Regulation * Enforcement } & & & $-0.007 * * *$ & & & $-0.013 * *$ \\
\hline & & & $(0.000)$ & & & $(0.018)$ \\
\hline \multirow[t]{2}{*}{ Accounting Regulation } & $-0.288 * * *$ & $-0.272 * * *$ & -0.147 & $-0.329 * * *$ & $-0.319 * * *$ & -0.084 \\
\hline & $(0.000)$ & $(0.000)$ & $(0.190)$ & $(0.000)$ & $(0.000)$ & $(0.362)$ \\
\hline \multirow[t]{2}{*}{ Enforcement } & $-0.072 * * *$ & $-0.068 * * *$ & -0.031 & $-0.060 * * *$ & $-0.055^{* * *}$ & 0.013 \\
\hline & $(0.000)$ & $(0.000)$ & $(0.310)$ & $(0.000)$ & $(0.000)$ & $(0.615)$ \\
\hline Country-level control variables & Yes & Yes & Yes & Yes & Yes & Yes \\
\hline Firm-level control variables & Yes & Yes & Yes & Yes & Yes & Yes \\
\hline Country effects & Yes & No & No & Yes & No & No \\
\hline Year effects & Yes & Yes & Yes & Yes & Yes & Yes \\
\hline Observations & 1711 & 1232 & 1232 & 1711 & 1232 & 1232 \\
\hline R-squared & 0.770 & 0.725 & 0.726 & 0.819 & 0.881 & 0.882 \\
\hline
\end{tabular}

Table 4 presents the impact of accounting regulations and enforcement. We present the definitions of all of the variables in Table 1 . We report $p$ values in parentheses. We use ***, and *** to indicate $10 \%, 5 \%$, and $1 \%$ significance levels, respectively. 
Table 5. Individual Impacts of Regulations

\begin{tabular}{|c|c|c|c|c|}
\hline \multirow[t]{2}{*}{ Dependent Variable } & \multicolumn{2}{|c|}{ Negative Skewness } & \multicolumn{2}{|c|}{ Down Up Volatility } \\
\hline & (1) & (2) & (3) & (4) \\
\hline \multirow[t]{2}{*}{ SQ1 * Enforcement } & & 0.143 & & 0.112 \\
\hline & & $(0.667)$ & & $(0.623)$ \\
\hline \multirow[t]{2}{*}{ SQ2 * Enforcement } & & $-0.911 * * *$ & & $-0.854 * * *$ \\
\hline & & $(0.000)$ & & $(0.000)$ \\
\hline \multirow[t]{2}{*}{ SQ3 * Enforcement } & & $-0.032 * * *$ & & $-0.039 * * *$ \\
\hline & & $(0.000)$ & & $(0.000)$ \\
\hline \multirow[t]{2}{*}{ SQ4 * Enforcement } & & $-0.004 * * *$ & & $-0.006 * * *$ \\
\hline & & $(0.000)$ & & $(0.000)$ \\
\hline \multirow[t]{2}{*}{ SQ5 * Enforcement } & & $-0.771 * * *$ & & $-0.757 * * *$ \\
\hline & & $(0.000)$ & & $(0.000)$ \\
\hline \multirow[t]{2}{*}{ SQ6 * Enforcement } & & $-0.009 * * *$ & & $-0.020 * * *$ \\
\hline & & $(0.000)$ & & $(0.000)$ \\
\hline \multirow[t]{2}{*}{ SQ1 } & -0.339 & -3.121 & -0.385 & -2.582 \\
\hline & $(0.700)$ & $(0.900)$ & $(0.650)$ & $(0.606)$ \\
\hline \multirow[t]{2}{*}{ SQ2 } & $-0.443 *$ & 11.610 & $-0.558^{*}$ & 10.847 \\
\hline & $(0.079)$ & $(0.600)$ & $(0.053)$ & $(0.770)$ \\
\hline \multirow[t]{2}{*}{ SQ3 } & $-0.121 * * *$ & 0.433 & $-0.248 * *$ & 0.422 \\
\hline & $(0.001)$ & $(0.407)$ & $(0.010)$ & $(0.389)$ \\
\hline \multirow[t]{2}{*}{ SQ4 } & $-0.284 * * *$ & -0.439 & $-0.331 * * *$ & -0.283 \\
\hline & $(0.000)$ & $(0.172)$ & $(0.000)$ & $(0.389)$ \\
\hline \multirow[t]{2}{*}{ SQ5 } & $-0.111 * * *$ & -8.094 & $-0.118 * * *$ & -8.001 \\
\hline & $(0.008)$ & $(0.660)$ & $(0.001)$ & $(0.770)$ \\
\hline \multirow[t]{2}{*}{ SQ6 } & $-0.060 * * *$ & -0.392 & $-0.072 * * *$ & -0.612 \\
\hline & $(0.000)$ & $(0.553)$ & $(0.001)$ & $(0.105)$ \\
\hline \multirow[t]{2}{*}{ Enforcement } & $-0.093 * * *$ & -0.061 & $-0.084 * * *$ & -0.055 \\
\hline & $(0.000)$ & $(0.602)$ & $(0.000)$ & $(0.704)$ \\
\hline Country-level control variables & Yes & Yes & Yes & Yes \\
\hline Firm-level control variables & Yes & Yes & Yes & Yes \\
\hline Year effects & Yes & Yes & Yes & Yes \\
\hline Observations & 1232 & 1232 & 1232 & 1232 \\
\hline R square & 0.709 & 0.723 & 0.856 & 0.880 \\
\hline
\end{tabular}

Panel A of Table 5 presents the individual impacts of accounting regulations. The variable Accounting Regulation consists of the following six World Bank survey questions: "(SQ1) Does accrued, though unpaid interest/principal enter the income statement while the loan is still performing? (SQ2) Are financial institutions required to produce consolidated accounts covering all bank and any nonbank financial subsidiaries? (SQ3) Are off-balance sheet items disclosed to the public? (SQ4) Must banks disclose their risk management procedures to the public? (SQ5) Are bank directors legally liable if information disclosed is erroneous or misleading? (SQ6) Does accrued, though unpaid interest/principal enter the income statement while the loan is still nonperforming? ( 1 if it is No; 0 otherwise.)" Barth et al., (2006).

We present the variable definitions in Table 1 . We report $p$-values in parentheses. We use *, ${ }^{* *}$, and $* * *$ to indicate $10 \%, 5 \%$, and $1 \%$ significance levels, respectively. 
Panel B

\begin{tabular}{lcccc}
\hline \multirow{2}{*}{ Dependent Variable } & \multicolumn{2}{c}{ Negative Skewness } & \multicolumn{2}{c}{ Down Up Volatility } \\
\cline { 2 - 4 } & $(1)$ & $(2)$ & $(3)$ & $(4)$ \\
\hline Accounting Regulation * External Audit & & $-0.017^{* * *}$ & & $-0.004^{* * *}$ \\
& & $(0.009)$ & $(0.001)$ \\
Accounting Regulation * External Monitoring & & 0.033 & & 0.003 \\
& & $(0.509)$ & & $(0.737)$ \\
Accounting Regulation * Direct Supervision & & $-0.017 * *$ & & $-0.013^{* *}$ \\
& & $(0.016)$ & & $(0.022)$ \\
External Audit & $-0.085^{* * *}$ & -0.176 & $-0.085^{* * *}$ & -0.062 \\
& $(0.000)$ & $(0.154)$ & $(0.000)$ & $(0.615)$ \\
External Monitoring & -0.092 & -0.270 & -0.081 & -0.101 \\
& $(0.600)$ & $(0.670)$ & $(0.710)$ & $(0.077)$ \\
Direct Supervision & $-0.060^{* * *}$ & 0.034 & $-0.045^{* * *}$ & 0.023 \\
& $(0.000)$ & $(0.350)$ & $(0.000)$ & $(0.471)$ \\
Accounting Regulation & $-0.268^{* * *}$ & -0.310 & $-0.318^{* * *}$ & -0.189 \\
& $(0.000)$ & $(0.196)$ & $(0.000)$ & $(0.267)$ \\
\hline Country-level control variables & Yes & Yes & Yes & Yes \\
Firm-level control variables & Yes & Yes & Yes & Yes \\
Year effects & Yes & Yes & Yes & Yes \\
\hline Observations & 1232 & 1232 & 1232 & 1232 \\
R-squared & 0.728 & 0.729 & 0.886 & 0.886 \\
\hline
\end{tabular}

Panel B of Table 5 presents the individual impact of enforcement regulations. The variable Enforcement includes the three enforcement regulation variables External Audit, External Monitoring, and Direct Supervision. We present the variable definitions in Table 1 . We report $p$-values in parentheses. We use *, $* *$, and $* * *$ to indicate $10 \%, 5 \%$, and $1 \%$ significance levels, respectively. 
Table 6. Endogeneity Tests

Panel A

\begin{tabular}{lcccc}
\hline \multirow{2}{*}{ Dependent Variable } & \multicolumn{2}{c}{$\Delta$ Negative Skewness } & \multicolumn{2}{c}{$\Delta$ Down Up Volatility } \\
\cline { 2 - 5 } & $(1)$ & $(2)$ & $(3)$ & $(4)$ \\
\hline Accounting Regulation * $\Delta$ Enforcement & & $-0.005^{* *}$ & & $-0.004^{* *}$ \\
& & $(0.029)$ & & $(0.020)$ \\
$\Delta$ Accounting Regulation & $-0.290^{* * *}$ & -0.289 & $-0.382^{* * *}$ & -0.383 \\
& $(0.000)$ & $(0.550)$ & $(0.000)$ & $(0.670)$ \\
$\Delta$ Enforcement & $-0.058^{* * *}$ & -0.058 & $-0.041^{* * *}$ & -0.041 \\
& $(0.000)$ & $(0.770)$ & $(0.000)$ & $(0.870)$ \\
\hline Country-level control variables & Yes & Yes & Yes & Yes \\
Firm-level control variables & Yes & Yes & Yes & Yes \\
Year effects & Yes & Yes & Yes & Yes \\
\hline Observations & 684 & 684 & 684 & 684 \\
R-squared & 0.614 & 0.614 & 0.874 & 0.873 \\
\hline
\end{tabular}

Panel A of Table 6 presents the results of change regressions. We present the variable definitions in Table 1 . We report $p$-values in parentheses. We use $*, * *$, and $* * *$ to indicate $10 \%, 5 \%$, and $1 \%$ significance levels, respectively. 


\begin{tabular}{|c|c|c|c|c|c|c|}
\hline Dependent Variable & $\begin{array}{l}\text { Accounting } \\
\text { Regulation }\end{array}$ & Enforcement & $\begin{array}{l}\text { Negative } \\
\text { Skewness }\end{array}$ & $\begin{array}{l}\text { Negative } \\
\text { Skewness }\end{array}$ & $\begin{array}{l}\text { Down Up } \\
\text { Volatility }\end{array}$ & $\begin{array}{l}\text { Down Up } \\
\text { Volatility }\end{array}$ \\
\hline & $(1)$ & $(2)$ & $(3)$ & (4) & $(5)$ & $(6)$ \\
\hline $\begin{array}{l}\text { Fitted Accounting Regulation * } \\
\text { Fitted Enforcement }\end{array}$ & & & & $\begin{array}{c}-0.037 * * * \\
(0.005)\end{array}$ & & $\begin{array}{c}-0.063 * * \\
(0.034)\end{array}$ \\
\hline Fitted Accounting Regulation & & & $\begin{array}{c}-0.270 * * * \\
(0.000)\end{array}$ & $\begin{array}{c}0.530 \\
(0.388)\end{array}$ & $\begin{array}{c}-0.293 * * * \\
(0.002)\end{array}$ & $\begin{array}{c}1.091 \\
(0.688)\end{array}$ \\
\hline Fitted Enforcement & & & $\begin{array}{c}-0.068 * * * \\
(0.001)\end{array}$ & $\begin{array}{c}0.120 \\
(0.425)\end{array}$ & $\begin{array}{c}-0.049 * * \\
(0.032)\end{array}$ & $\begin{array}{c}0.277 \\
(0.773)\end{array}$ \\
\hline Avg Accounting Regulation & $\begin{array}{c}0.173 * * * \\
(0.009)\end{array}$ & $\begin{array}{c}3.997 * * * \\
(0.000)\end{array}$ & & & & \\
\hline Avg Enforcement & $\begin{array}{c}0.055^{* * *} \\
(0.009) \\
\end{array}$ & $\begin{array}{c}0.538 * * * \\
(0.000) \\
\end{array}$ & & & & \\
\hline Country-level control variables & Yes & Yes & Yes & Yes & Yes & Yes \\
\hline Firm-level control variables & No & No & Yes & Yes & Yes & Yes \\
\hline Year effects & Yes & Yes & Yes & Yes & Yes & Yes \\
\hline Observations & 1031 & 1031 & 1031 & 1031 & 1031 & 1031 \\
\hline R-squared & 0.690 & 0.822 & 0.645 & 0.649 & 0.771 & 0.785 \\
\hline
\end{tabular}

Panel B of Table 6 presents the results of instrumental variable regressions. We present the variable definitions in Table 1. We report the results in the first stage in Columns (1) and (2). We report $p$-values in parentheses. We use *, **, and *** to indicate $10 \%, 5 \%$, and $1 \%$ significance levels, respectively. 
Panel C

\begin{tabular}{lcc}
\hline Dependent Variable & Negative Skewness & Down Up Volatility \\
\hline Accounting Regulation * Democracy Quality & $(1)$ & $-0.003 * * *$ \\
& $-0.002 * * *$ & $(0.001)$ \\
Enforcement * Democracy Quality & $(0.007)$ & $0.001^{* * *}$ \\
& $-0.001^{* * *}$ & $(0.009)$ \\
Accounting Regulation & $(0.003)$ & -0.315 \\
& -0.267 & $(0.650)$ \\
Enforcement & $(0.600)$ & -0.064 \\
& -0.065 & $(0.670)$ \\
\hline Country-level control variables & $(0.550)$ & Yes \\
Firm-level control variables & Yes & Yes \\
Year effects & Yes & Yes \\
\hline Observations & Yes & 1232 \\
R-squared & 1232 & 0.880 \\
\hline
\end{tabular}

Panel C of Table 6 presents the effects of the interactions between our regulation variables and Democracy Quality. We present the variable definitions in Table 1 . We report $p$-values in parentheses. We use *,**, and *** to indicate $10 \%, 5 \%$, and $1 \%$ significance levels, respectively. 


\section{Table 7. Tests in the Subsample}

\begin{tabular}{|c|c|c|c|c|c|c|c|c|}
\hline \multirow[t]{3}{*}{ Dependent Variable } & \multicolumn{2}{|c|}{ Negative Skewness } & \multicolumn{2}{|c|}{ Down Up Volatility } & \multicolumn{2}{|c|}{ Negative Skewness } & \multicolumn{2}{|c|}{ Down Up Volatility } \\
\hline & \multicolumn{4}{|c|}{ Small Bank } & \multicolumn{4}{|c|}{ Large Bank } \\
\hline & $(1)$ & $(2)$ & (3) & (4) & $(5)$ & (6) & $(7)$ & $(8)$ \\
\hline \multirow[t]{2}{*}{ Accounting Regulation * Enforcement } & & $-0.002 * * *$ & & $-0.007 *$ & & $-0.010 * * *$ & & $-0.023 * * *$ \\
\hline & & $(0.002)$ & & $(0.064)$ & & $(0.007)$ & & $(0.001)$ \\
\hline \multirow[t]{2}{*}{ Accounting Regulation } & $-0.222 * * *$ & -0.183 & $-0.330 * * *$ & -0.200 & $-0.324 * * *$ & -0.138 & $-0.351 * * *$ & 0.074 \\
\hline & $(0.000)$ & $(0.159)$ & $(0.000)$ & $(0.808)$ & $(0.000)$ & $(0.270)$ & $(0.000)$ & $(0.486)$ \\
\hline \multirow[t]{2}{*}{ Enforcement } & $-0.071 * * *$ & -0.059 & $-0.054 * * *$ & -0.017 & $-0.070^{* * *}$ & -0.017 & $-0.060 * * *$ & 0.060 \\
\hline & $(0.000)$ & $(0.105)$ & $(0.000)$ & $(0.407)$ & $(0.000)$ & $(0.614)$ & $(0.000)$ & $(0.774)$ \\
\hline Country-level control variables & Yes & Yes & Yes & Yes & Yes & Yes & Yes & Yes \\
\hline Firm-level control variables & Yes & Yes & Yes & Yes & Yes & Yes & Yes & Yes \\
\hline Year effects & Yes & Yes & Yes & Yes & Yes & Yes & Yes & Yes \\
\hline Observations & 575 & 575 & 575 & 575 & 657 & 657 & 657 & 657 \\
\hline R-squared & 0.694 & 0.694 & 0.860 & 0.861 & 0.750 & 0.751 & 0.900 & 0.904 \\
\hline
\end{tabular}

Table 7 presents the results in the subsamples, including small and large banks. We present the variable definitions in Table 1 . We report $p$-values in parentheses. We use $*, * *$, and $* * *$ to indicate $10 \%, 5 \%$, and $1 \%$ significance levels, respectively. 
Table 8. Alternative Variables of Enforcement Regulations

\begin{tabular}{|c|c|c|c|c|c|c|c|c|}
\hline \multirow[t]{2}{*}{ Dependent Variable } & \multicolumn{2}{|c|}{ Negative Skewness } & \multicolumn{2}{|c|}{ Down Up Volatility } & \multicolumn{2}{|c|}{ Negative Skewness } & \multicolumn{2}{|c|}{ Down Up Volatility } \\
\hline & $(1)$ & $(2)$ & (3) & (4) & $(5)$ & (6) & (7) & $(8)$ \\
\hline $\begin{array}{l}\text { Accounting Regulation * External Audit \& } \\
\text { Direct Supervision }\end{array}$ & & $\begin{array}{c}-0.010 * * * \\
(0.007)\end{array}$ & & $\begin{array}{c}-0.018 * * \\
(0.023)\end{array}$ & & & & \\
\hline Accounting Regulation * Direct Supervision & & & & & & $\begin{array}{c}-0.018 * * * \\
(0.008)\end{array}$ & & $\begin{array}{c}-0.020 * * \\
(0.048)\end{array}$ \\
\hline Accounting Regulation & $\begin{array}{c}-0.282 * * * \\
(0.000)\end{array}$ & $\begin{array}{l}-0.132 \\
(0.446)\end{array}$ & $\begin{array}{c}-0.336 * * * \\
(0.000)\end{array}$ & $\begin{array}{l}-0.056 \\
(0.623)\end{array}$ & $\begin{array}{c}-0.294 * * * \\
(0.000)\end{array}$ & $\begin{array}{l}-0.139 \\
(0.190)\end{array}$ & $\begin{array}{c}-0.343^{* * *} \\
(0.000)\end{array}$ & $\begin{array}{l}-0.169 \\
(0.132)\end{array}$ \\
\hline Audit\&DirectSup & $\begin{array}{c}-0.073 * * * \\
(0.000)\end{array}$ & $\begin{array}{l}-0.022 \\
(0.698)\end{array}$ & $\begin{array}{c}-0.058 * * * \\
(0.000)\end{array}$ & $\begin{array}{c}0.037 \\
(0.344)\end{array}$ & & & & \\
\hline Direct Supervision & & & & & $\begin{array}{c}-0.049 * * * \\
(0.000)\end{array}$ & $\begin{array}{c}0.041 \\
(0.521) \\
\end{array}$ & $\begin{array}{c}-0.034 * * * \\
(0.000)\end{array}$ & $\begin{array}{c}0.067 \\
(0.173) \\
\end{array}$ \\
\hline Country-level control variables & Yes & Yes & Yes & Yes & Yes & Yes & Yes & Yes \\
\hline Firm-level control variables & Yes & Yes & Yes & Yes & Yes & Yes & Yes & Yes \\
\hline Year effects & Yes & Yes & Yes & Yes & Yes & Yes & Yes & Yes \\
\hline Observations & 1232 & 1232 & 1232 & 1232 & 1232 & 1232 & 1232 & 1232 \\
\hline R-squared & 0.713 & 0.713 & 0.869 & 0.870 & 0.694 & 0.695 & 0.850 & 0.852 \\
\hline
\end{tabular}

Table 8 presents the results when employing alternative measures of enforcement. We present the variable definitions in Table 1 . We report $p$-values in parentheses. We use $*, * *$, and $* * *$ to indicate $10 \%, 5 \%$, and $1 \%$ significance levels, respectively. 